\title{
What Makes a Good School Inspector? A Case Study of Teachers' and School Administrators' Perceptions of School Inspectors
}

Nurul Jawahir Md Ali, Suhaida Abdul Kadir, Steven Eric Krauss, \& Arnida Abdullah

To Link this Article: http://dx.doi.org/10.6007/IJARBSS/v11-i12/11901～DOI:10.6007/IJARBSS/v11-i12/11901

Received: 06 October 2021, Revised: 07 November 2021, Accepted: 26 November 2021

Published Online: 16 December 2021

In-Text Citation: (Ali et al., 2021)

To Cite this Article: Ali, N. J. M., Kadir, S. A., Krauss, S. E., \& Arnida, A. (2021). What Makes a Good School Inspector? A Case Study of Teachers' and School Administrators' Perceptions of School Inspectors. International Journal of Academic Research in Business and Social Sciences, 11(12), 1732-1745.

Copyright: (c) 2021 The Author(s)

Published by Human Resource Management Academic Research Society (www.hrmars.com) This article is published under the Creative Commons Attribution (CC BY 4.0) license. Anyone may reproduce, distribute, translate and create derivative works of this article (for both commercial and non0-commercial purposes), subject to full attribution to the original publication and authors. The full terms of this license may be seen at: http://creativecommons.org/licences/by/4.0/legalcode

Vol. 11, No. 12, 2021, Pg. $1732-1745$

Full Terms \& Conditions of access and use can be found at http://hrmars.com/index.php/pages/detail/publication-ethics 


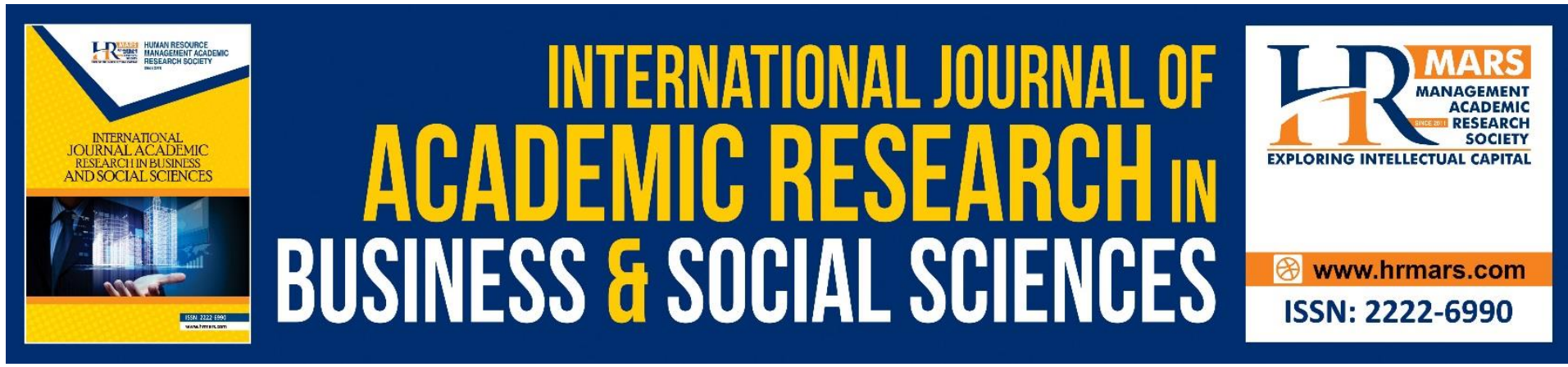

\title{
What Makes a Good School Inspector? A Case Study of Teachers' and School Administrators' Perceptions of School Inspectors
}

\author{
Nurul Jawahir Md Ali, Suhaida Abdul Kadir, Steven Eric Krauss, \\ \& Arnida Abdullah \\ Faculty of Educational Studies, Universiti Putra Malaysia, 43400 UPM Serdang, Selangor, \\ Malaysia \\ Corresponding Author: suhaida@upm.edu.my
}

\begin{abstract}
A school inspector's characteristics are important in ensuring that the school inspection process goes well as this may lead to the school's improvement while preventing the occurrence of side effects. This study aims to explore teachers' and school administrators' perceptions of school inspectors after experiencing school inspections. Using qualitative case studies, nine participants from two schools were interviewed. This study discovered that the participants had positive perceptions of school inspectors. Through thematic analysis, four descriptions of school inspectors' characteristics emerged, namely 'friendly and kind', 'helpful communication style', 'understanding and considerate' and 'provide recognition'. The positive demeanour of school inspectors was found to be valuable in minimising stress and fear amongst inspectees while making the inspection process easier and more meaningful, as well as enabling the participants to learn and improve their work. This study recommends that school inspectors have positive attitudes and approaches to conducting inspections as this can make the process easier for inspectees and encourage them to be positive about the process while limiting unwanted effects like stress. Finally, future studies should explore the relationship between school inspectors' characteristics and schools' improvements as the outcome of school inspections.
\end{abstract}

Keywords: School Inspection, School Inspector, Perception, Teacher, School Administrator

\section{Introduction}

Good education is the desire of every nation. To achieve this, the school inspection has become one of the instruments used to maintain the quality of education. School inspections serve to determine that schools are functioning accordingly and accountable for what they are doing while ensuring that school improvements occur at the same time (OECD, 2013). Thus, the school inspection has been deemed the guardian of educational standards (MacBeath, 2006).

In Malaysia, school inspections also play an important part in safeguarding the quality of education and governing the education system by ensuring the schools' compliance with educational standards (Ministry of Education Malaysia, 2015). The school inspection is 
conducted by a school inspector under the entity known as the School Inspectorate or Jemaah Nazir (JN).

The characteristics of the school inspection, as performed by the inspector, are important in promoting the desirable effects of the school inspection. For example, school improvements should take place without unwanted effects like intended strategic activities (e.g., fraud or misrepresentation) or emotional side effects occurring at the same time (Ehren \& Visscher, 2006). The way the inspector behaves whilst interacting with school members can affect the experience and outcome of the school inspection, as it can determine whether the process is meaningful and impactful to both the school and its members or otherwise (Alexius, 2018; Behnke \& Steins, 2017; Brimblecombe et al., 1995; Ehren \& Visscher, 2006).

Not many studies have been conducted regarding teachers' and school administrators' experience and perceptions of school inspections in Malaysia. One study by Tahir et al (2018), however, has discovered that criticism from school inspectors has become one of the factors contributing to the stress experienced by deputy heads in primary schools. This finding hinted that their interaction with school inspectors put them under pressure, which was partly due to the truculent behaviour of the inspector. However, their study was not performed directly after a school inspection. Instead, it was conducted by using a mixed-methods approach to understand the general experience of stress that affected deputy heads across 45 primary schools.

To gain more thorough information about inspectees' perceptions of school inspectors, one should study the inspectees' experience after they had undergone the inspection process itself. Therefore, this study intended to study inspectees' (which included both teachers and school administrators) perceptions of school inspectors' characteristics while conducting examinations after having a school inspection. The study used a qualitative case study approach, which can offer an in-depth exploration of the topic.

\section{Perceptions of School Inspectors}

Previous literature has revealed inconsistencies regarding school members' perceptions of school inspectors and the school inspection process. Some have discovered positive impressions of school inspectors while others uncovered negative ones. It is unsurprising that the school inspection process could produce undesirable feelings among the inspectees as it is a form of accountability system, and such systems entail uneasy sensations like stress (FitzGibbon, 1997; Smith, 1995).

Some studies have depicted school inspections as unpleasant and intimidating activities (Haris et al., 2018; Hopkins et al., 2016; Moreton, 2015). Other studies (De Grauwe, 2008; Wanzare, 2002) have revealed the use of hostile and intimidating tones of voice among school inspectors. Besides, school inspectors have been accused of focusing on finding teachers' mistakes and acting harshly towards them in front of the pupils (Moswela, 2010; Wanzare, 2002). The 'looking for fault' attitude among inspectors has been perceived by school principals as the intention to damage the school (Behnke \& Steins, 2017) as well as teachers' professionalism (Hopkins et al., 2016). Dissatisfaction with the school inspection process has also occurred due to scepticism towards the measurement instruments used for the process and the insufficient support schools have received (Behnke \& Steins, 2017). Some negative perceptions stemmed from the inconvenient timing of inspections (Tahir et al., 2018) and the increased workload of preparing documents and evidence before inspections (Hult \& Segerholm, 2016; Male, 2006; Tahir et al., 2018). These issues resulted in teachers and school 
administrators experiencing stress (Brimblecombe et al., 1996; de Wolf \& Janssens, 2007; Hamzah \& Tahir, 2013; Penninckx et al., 2015; Perryman, 2007).

Positive perceptions of school inspections have been revealed to be linked with existing and previous experiences of school inspections, the recognition of a principal's work and the positive attitude of the school inspector (Behnke \& Steins, 2017). The feedback given by school inspectors has also contributed to positive attitudes among teachers towards school inspections (Behnke \& Steins, 2017; Quintelier et al., 2018; Segerholm \& Hult, 2016).

\section{Theoretical Framework}

A framework that describes the effect of school inspections was constructed by Ehren and Visscher (2006). Their framework included an aspect known as 'features of school inspection', which illustrates the characteristics of the school inspection process. This aspect consists of four dimensions, as described below (Ali et al., 2021; Ehren \& Visscher, 2006):

i. Degree of reciprocity and trust in the relationships: the relationship between school inspectors and schools that could lead schools to have open attitudes to recognising their strengths and weaknesses, as well as to act upon recommendations;

ii. Communication style - this is identified through the dimensions of 'power', which relate to the degree to which the inspector provides directions for the interaction process; and 'nearness', which refers to the emotional distance between the inspector and the other participants in the interaction process in the inspection context;

iii. Nature of the feedback: the provision of feedback and its characteristics can influence a school's acceptance of and response to the inspection;

iv. Preventing undesirable behaviour of schools: the practice of school inspections that can be organised to prevent negative side effects.

From this framework, this study focused on these four aspects - the relationship and trust between inspectors and inspectees; style of communication; the characteristics of giving feedback; and the inspector's manner, which may reduce or prevent the occurrence of negative side effects, including stress. Instead of giving attention to the content of the feedback itself, we aim to study the teachers' and administrators' opinions of each inspector's approach, personality and demeanour while conducting a school inspection. As reported by Tahir et al (2018), the criticisms made by school inspectors have become a contributor to stress among deputy heads. While their study focused specifically on the experience of stress amongst deputies, the current authors want to determine the experiences produced by the inspections throughout the time spent interacting and engaging with the school inspectors; the aim is not to focus on stress as a side effect. By employing a qualitative case study approach, we interviewed inspectees (teachers and school administrators) to ascertain what kind of perceptions they had of school inspectors after undergoing the inspection process and how the inspector's manner affected their experience.

\section{Methodology}

\section{Research Design}

This study employed a qualitative case study approach, which is appropriate to explore a phenomenon of interest that exists within a bounded system (Merriam, 1998; Merriam \& Tisdell, 2016). This was the most effective way to capture the experience and perceptions that school personnel had of school inspectors during an event. Two schools were selected for this study, Bukit Secondary School (BSS) and Tanjung Primary School (TPS). Both schools were 
situated in Negeri Sembilan and were chosen for the same purpose, which was related to their involvement in the implementation of the Transformation School Program 2025. The goal of the inspection was to examine and evaluate the schools' performance in various areas, including the leadership role, the quality of teaching and learning, and parental involvement.

\section{Sampling and Participants}

To obtain a better understanding of the case or phenomenon being studied, a researcher should choose participants who have information, knowledge and understanding of the issue (Creswell, 2012; Richards \& Morse, 2013). Hence, this study used a purposeful sampling approach. The criteria for the targeted participants were that they should be teachers or school administrators involved with the TS25 inspection and that they had been either observed or interviewed by the school inspector. The criteria were given to each schools' headmaster and principal, who provided the names and contact numbers of the teachers and administrators involved. Each participant was assigned a pseudonym to protect their identity. A description of the research participants is provided in Table 1.

Table 1 Description of the research participants

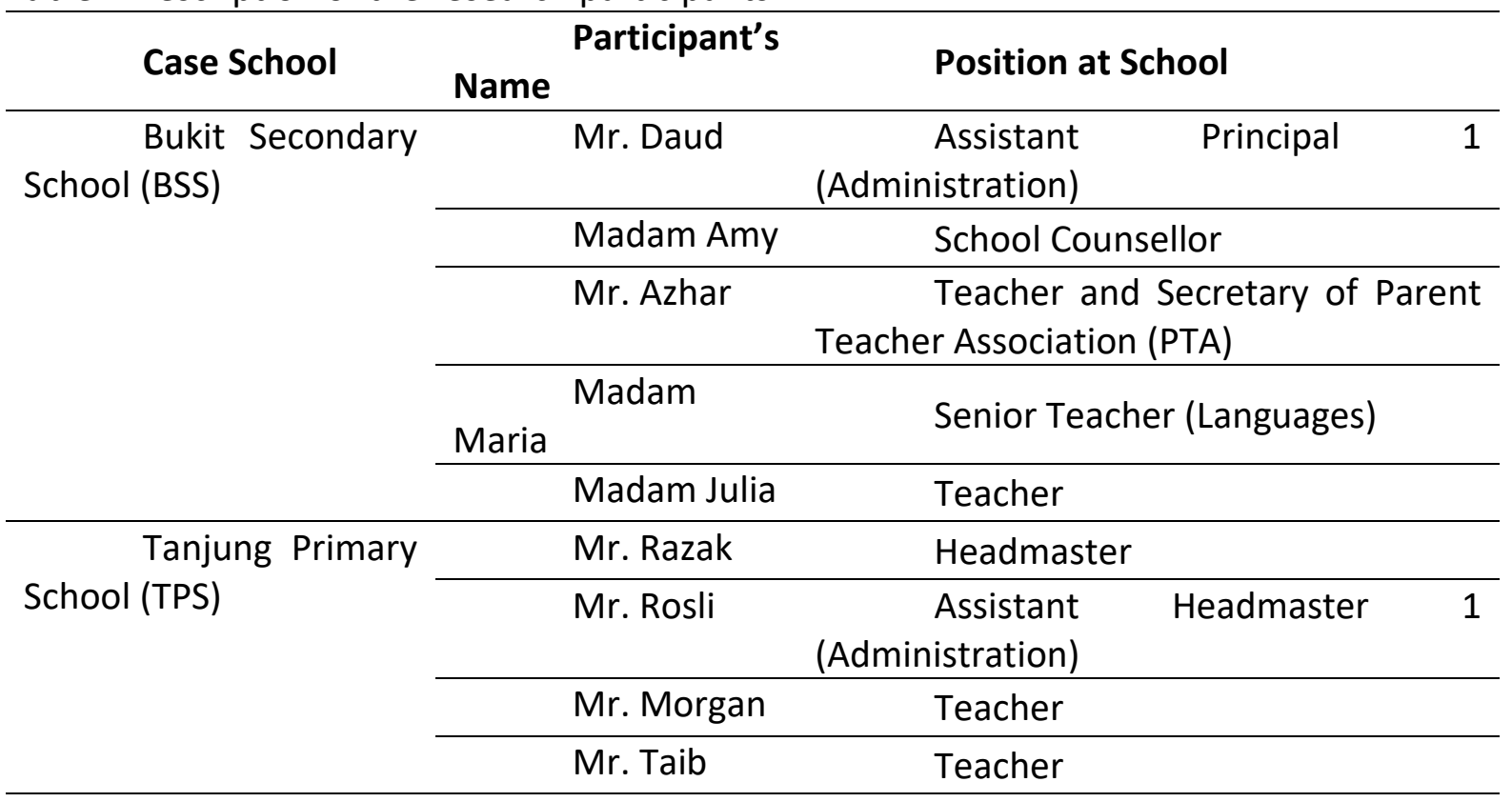

\section{Data Analysis}

The data were analysed using thematic analysis, which was conducted in two phases - first, the within-case and secondly, the cross-case analysis. The interview recordings were transcribed to produce the interview transcripts. To aid data management, all the transcriptions were kept in a designated folder and unique names were assigned to each transcript according to the case and its participants. The researchers listened to the interview audios and read the interview transcripts several times to gain familiarity with the data and foster a good understanding of the participants' points of view, which enabled the researchers to develop the code and interpret the findings more effectively.

Next, all the interview transcripts were uploaded into ATLAS.ti software and coded according to each case. The interview excerpts that answered the research question were selected and the name of the finding that represented the data was assigned a code. Then, the findings were categorised by creating a 'code group', which grouped and clustered similar findings 
together to develop categories. Finally, the case categories were compared and contrasted to understand the findings as a whole and enable the participants' perceptions of school inspectors to be described.

\section{Findings}

Overall, this study discovered that the participants had positive perceptions of the school inspector who had inspected their school. The findings were classified into four categories: A) friendly and kind, B) helpful communication style, C) understanding and considerate and D) provide recognition. A description of each category is provided in Table 2.

Table 2 Description of 'good school inspector' theme and categories

\begin{tabular}{cl}
\hline Categories & Description \\
\hline A. Friendly and kind & $\begin{array}{l}\text { School inspectors are kind and friendly, which reduces the } \\
\text { fears that teachers and administrators have and makes the } \\
\text { school inspection process easier. } \\
\text { Less formal style of interaction between the inspector and } \\
\text { the teacher; the use of positive language and a tone of voice } \\
\text { that eases the process. }\end{array}$ \\
$\begin{array}{ll}\text { B. Helpful } \\
\text { communication style }\end{array}$ \\
$\begin{array}{ll}\text { C. Understanding ansiderate } \\
\text { D. Provide recognition }\end{array}$ & $\begin{array}{l}\text { teachers' context. } \\
\text { Inspectors recognised and praised teachers' efforts. }\end{array}$ \\
\hline
\end{tabular}

\section{a. Friendly and Kind}

This study found that participants described school inspectors as kind and friendly. This personality helped to calm the participants and reduce their fears. It also changed the initial perceptions amongst teachers and administrators in relation to school inspectors. Table 3 below presents the findings. 
Table 3 Findings for the 'friendly and kind' category

\begin{tabular}{l} 
School Interview Excerpts Based on Findings \\
\hline Kind and didn't focus on finding fault \\
\hline BSS I am truly grateful to be inspected by a kind and friendly inspector. I used to have \\
the experience of being examined by a different officer and the situation was \\
different. This time, when [the current officer] inspected me, she didn't highlight \\
whether I didn't do my work nor look for my mistakes straightaway." - Azhar \\
"The inspectors who came here, I praise them. They didn't come with the intention \\
to find fault. They were all [kind] indeed, and the four of them are very \\
friendly...really kind." - Razak \\
Inspector made teachers and administrators feel calm and safe, which reduced their fear \\
\hline BSS "Personally, for me, when the inspector wants to come for the first time, I was \\
like, I'm dead! I'm finished, what should I answer? Because we know that we'll be \\
dealing with the inspector. But when she came into the class, after she observed \\
my teaching and after she guided me, I became okay. I am happy with this \\
inspector, maybe because she helped me. Maybe [it was] because the inspector \\
who inspected me was friendly and used [a warm] touch, saying 'Julia, don't be \\
scared'." - Julia \\
"To me, she makes the people that meet her feel calm. We feel ... like we are not \\
in an unsafe [situation] so we are willing to share what we know based on [the] \\
things that she wants." - Amy \\
"They are not fierce. They greeted us. When we met them, their feedback too was \\
given with smiling faces. When they have questions, I can spontaneously smile and \\
answer, since their character makes it easy. Indeed, they are professional. The one \\
that came into my classroom is professional too. The way he treats me is \\
professional and kind...They were friendly, unlike [we had been] told by other \\
teachers." - Morgan
\end{tabular}

The researchers identified that, according to the perceptions of the staff at both TPS and BSS, the inspectors' personalities were described as kind and they had friendly dispositions. From the interview excerpts of Azhar and Razak, they both felt that the inspectors did not show the characteristics and intention to look for mistakes. Julia, Amy and Morgan also described how the inspector made them feel calm and safe, which reduced their fear. Thus, having an experience with a good, kind and friendly inspector turned the previous perceptions of inspections into positive impressions and helped teachers to be free of fear and stress.

\section{b. Helpful communication style}

This study also revealed that the participants perceived the school inspectors positively due to their helpful approach and style of communication. The style was described as less formal and without the power distance in communication, which promoted reciprocal relationships between the inspectors and participants, as well as the use of positive language and tones of voice. Table 4 below illustrates these findings. 
Table 4 Findings for the 'helpful communication strategy' category

\section{School Interview Excerpts Based on Findings}

Like having a conversation with a friend

BSS "She did not straightaway talk about work. Instead, she asked me where I live and conducted an icebreaking session first. We got to know each other... When we do not know anything about each other and an inspector asks us about lots of things, it's easier for us to get stressed. But she talks to me like a friend and I feel okay..." - Julia

TPS “...We were able to chat as friends. He told me where he'll be going next and his purpose of going there and asked me what I would do after this. I truly feel as if I know someone in a (superior) position. The way they communicate with the teachers is really friendly, not very assertive, and [it is] professional." - Morgan

\section{Do not push the participants and ask or suggest politely}

BSS "The inspector listens to what we want to say, she accepts it and she gave suggestions too. If I stated that such a thing is difficult for us to achieve, she didn't push us but tried to suggest and ask me what is doable for the school." - Daud

TPS "The way they communicate is pleasing to us, [and we] didn't felt like they tried to push us. The way they speak is good too and they're gentle and soft-spoken when they want to ask us questions." - Rosli

\begin{tabular}{ll}
\hline Gentle way of communicating and didn't make participants felt uncomfortable \\
\hline BSS "It's a normal interview, like a casual conversation. I didn't feel like I was being \\
interrogated and being asked repeatedly." - Maria \\
\hline " "... their communication style is really good and they clarified to us what they \\
wanted to request. To me, the officers who came here were not scary. We don't \\
feel that. Everything is good and acceptable." - Taib
\end{tabular}

The findings concerning the teachers' perceptions of school inspectors' communication style in both schools revealed the teachers' pleasant experiences and positive perceptions of the inspectors. From the interview excerpts, Julia and Morgan described how the inspector communicated with them as if they were friends. Being kind, friendly and able to interact with teachers as friends helped make the situation less intense, which allowed feelings of fear and stress to dissipate during the inspection process. In addition, the school inspectors did not push the participants and were not too assertive, as suggested by Daud and Rosli. Instead, they politely asked and gave suggestions to the participants. The inspectors' gentle ways of communicating didn't make the participants uncomfortable or as if they were under interrogation (as stated by Maria), nor did they make the teacher feel scared (as suggested by Taib). The inspectors' competence in maintaining casual and pleasant interactions with the teachers and administrators seemed to be beneficial in reducing and eliminating the feelings of fear and stress that the school staff had experienced.

\section{c. Understanding and Considerate}

Both case schools, BSS and TPS, were among the earliest school to be selected for the TS25 implementation. Before the first inspection, the administrators and teachers had little knowledge about the inspection requirements. That may have caused some weaknesses and deficiencies in the schools' practices, which were revealed during the first inspection. The weaknesses, however, could be addressed by the administrators when the inspectors showed consideration and understanding of their context. This finding captured the participants' 
perceptions of the positive character of the school inspectors in terms of their being understanding and considerate to the administrators and teachers. Table 5 below describes the findings under this category.

Table 5 Findings for the 'understanding and considerate' category

\begin{tabular}{|c|c|}
\hline \multicolumn{2}{|c|}{ School Interview Excerpts Based on Findings } \\
\hline \multicolumn{2}{|r|}{ Give time and opportunities for administrators to complete and prove their work } \\
\hline BSS & $\begin{array}{l}\text { "...all the documents that were kept in a file was missing. She gave me a chance } \\
\text { while she read to me her checklist. I was lucky because she gave me time and } \\
\text { asked me to look for it, so I tried to search for a soft copy in my old laptop. Thank } \\
\text { God, I found all the document soft copies in my old laptop, although the laptop } \\
\text { was supposed to be broken. She gave me the chance to submit it the next morning. } \\
\text { She asked me to leave it with her and she would call me if she needed anything } \\
\text { else. She asked me to go into the class first. For the second session, I was called } \\
\text { on to attend a meeting with the inspector via a school WhatsApp message. But } \\
\text { when I went to the meeting room, she said that I didn't have to participate and } \\
\text { [she] asked me to get some rest because I had been looking for the documents for } \\
\text { days. Therefore, she insisted that I get back and rest. During the reflection session, } \\
\text { I received a WhatsApp message from her. She congratulated me as I had } \\
\text { completed the submission of all the required documents. To me, the inspector } \\
\text { didn't put pressure on or blame the teachers, nor were they quick in making } \\
\text { judgements. They gave us the chance and time to prove our work." - Azhar }\end{array}$ \\
\hline TPS & $\begin{array}{l}\text { "In my experience, when he [the inspector] came to see me, he asked me to } \\
\text { explain the programs regarding student affairs. I was the Assistant Headmaster of } \\
\text { Student Affairs at that time. [He asked] "What are the student affairs programs } \\
\text { that you have conducted?" I told him and I mentioned the programs that our } \\
\text { school had conducted. He asked me back whether the programs had paperwork. I } \\
\text { said that some had paperwork while some didn't. Then he said, 'I want to write } \\
\text { the school's mark here [in the inspector's instrument], so you can try to look for } \\
\text { some of the paperwork first. Only then will I jot down the mark here. If there is } \\
\text { none, it's okay ... As long as there are any two [examples of] paperwork, we'll put } \\
\text { a mark.' I still remember the kind inspector." - Rosli }\end{array}$ \\
\hline \multicolumn{2}{|r|}{$\begin{array}{l}\text { Understand that administrators have other work to do too and give them time to } \\
\text { complete it first }\end{array}$} \\
\hline BSS & $\begin{array}{l}\text { "On the first day, the inspector told me to settle my work first. Then, on the second } \\
\text { day, I was available and able to focus [on the inspection] so I could give my } \\
\text { attention to it. I could give good responses, unlike the first day when I was } \\
\text { hectically handling the school camping booking and a student program in another } \\
\text { place. I asked her if I could manage my students first and I would get back to her } \\
\text { once I finished my work and she said okay. Therefore, I settled all my work first. } \\
\text { Luckily, the officer that I dealt with was very tolerant and understanding." - Amy }\end{array}$ \\
\hline
\end{tabular}

The administrators at both BSS and TPS described the school inspector as considerate and understanding. They provided time and opportunities for the administrators to complete and prove their work, and they showed understanding of the staff members' difficulties. In the interview excerpt, Azhar from BSS described his experience in detail. As the Parent Teacher Association Secretary, he had provided reports and relevant documents on previous 
examinations to the school administrators. However, all the prepared documentation had gone missing and was unable to be traced. Unfortunately, his computer was broken and he was unable to retrieve the original file. Feeling hopeless, he was fortunate that his difficulties received kind consideration from an inspector. The school inspectors' understanding and considerate attitudes were also revealed at TPS. Mr. Rosli was the only administrator involved with the first inspection of TPS to become a study participant. He said that some school programs under his administration (student affairs) had been executed without paperwork. Such an event might have caused the school to be given a poor score in the inspection report. However, the inspector gave him the chance to provide any relevant paperwork that might help the school to get a higher score from the inspection.

The BSS school inspection was conducted while the school was having an extra-curricular activity, a camping trip outside the school area. Therefore, almost half of the school staff were away organising that event. This meant BSS was understaffed during the inspection and one of the participants, Amy, was forced to handle multiple tasks at once. Amy experienced the inspection in a hectic situation since she played multiple roles. She had to ensure that her students participating in the Malaysian Future Leaders School could get transport safely to the program's location, while she was also replacing the school administrators in their role (these staff were absent as they were attending a school camp program in a separate location). She described her experience with a school inspector, who provided her with time to settle her work first. This finding did not occur at TPS, possibly due to the BSS context, whereby the school inspection happened at the same time as the school camping trip and other programs, which meant the staff were few in number and busy during the inspection. Understanding and being thoughtful of an administrator's situation at particular times, as shown by the inspector, turned the inspection into a pleasant experience and allowed the school administrators to demonstrate and settle their work.

\section{d. Provide Recognition}

This finding related to the moral support, appreciation and recognition offered by the inspectors to the teachers and administrators. One finding indicated that an inspector acknowledged the administrator's difficulties, while another finding revealed that the inspectors praised the teachers for their strength and the positive elements they implemented in their classroom. Table 6 below describes the findings regarding the recognition given by the school inspectors to the teachers and administrators. 
Table 6 Findings for the 'provide recognition' category

\begin{tabular}{l} 
School Interview Excerpts Based on Findings \\
\hline Recognise and appreciate the administrators' efforts \\
\hline "ThS inspector has recognised my effort. She appreciates my struggle and \\
announced [my performance] in the meeting that day, [saying] what I did and \\
what I had accomplished for the inspection. When I went to school the next day, \\
all the teachers congratulates me and I was so surprised by that: what should \\
they congratulate [me] about at this hour [early in the morning]? When asked, \\
all the teachers said that when they attended the reflection session yesterday, \\
the inspector praised me for my work, and everything was completed and I had \\
fulfilled the requirements. I was truly moved, because I was really sad when I \\
learnt that all the documents went missing. And when I tried my best to \\
complete my work and give it to her, she recognised [this] and give me \\
compliments. I was [so] deeply touched that I shed some tears." - Azhar \\
\hline Inspectors began by addressing teachers' strengths and recognising their work before \\
proceeding with suggestions for improvement \\
\hline "WSS \\
classroom activities, she praised all our efforts. Then, she continued with things \\
that I can improve. That's the reason I regarded this [feedback session with the \\
inspector] as advice, not a criticism." - Julia \\
"...after the observation, the inspector began to give his feedback. He said \\
'things that you do in the class are good, very good.' He began to praise me. \\
Then he said 'the set induction is good, [and] only small changes are needed'. \\
When he praised me, I felt happy. When he began to address [how] I could apply \\
some small changes, I felt a bit scared at the beginning. But then, it turned out \\
to be okay as it didn't seem like I was being criticised. He provided me with \\
guidance and gave me credit verbally. Indeed, when he gave me recognition of \\
what I had done, I felt so proud." - Morgan \\
"For me, after the classroom observation, the inspector started with good things \\
involved] positive comments and guidance." - Taib \\
TPS
\end{tabular}

In this section, the story of Azhar, the BSS PTA Secretary who had an issue with the missing work file (as narrated in the previous category 'understanding and considerate') continued. In the interview excerpt in Table 6, he described how the inspector acknowledged and praised his efforts. Azhar was eventually able to salvage the missing documents from his old laptop, which was broken and slow. That process took him the whole night until the next morning. During the inspection reflection session, which included administrators, some teachers and inspectors, the inspector requested that he take some rest (as reported in the previous category). After the session, he received a gesture of appreciation from the inspector and he was deeply moved by this. For Azhar, his hard work ended well as he had fulfilled all the documentation requirements for the inspection and had even received recognition from the inspector.

Referring to the classroom observation, as experienced by Julia from BSS, the inspector began their comments by pointing out the teacher's strengths. This way, the teacher perceived the feedback as advice. Morgan and Taib of Tanjung Primary School also told a similar story about 
their experiences of receiving feedback during the inspection. The inspectors began their comments by addressing the teachers' strengths and recognising their work before proceeding with suggestions for improvement.

The experiences of participants in both schools revealed that the inspectors showed their appreciation and recognition of the administrators' and teachers' work and effort. This approach turned the staff members' initial fears into positive experiences. For the classroom observation, the inspector started the feedback and one-to-one session by giving praise to the teacher, followed by positive advice to improve the teaching that was accepted by the teacher. Thus, the inspector's capability to recognise and show support to the teachers and administrators helped greatly in promoting a positive ambience during the inspection.

\section{Discussion and Conclusion}

Surprisingly, unlike the findings from some previous literature, this study revealed that school inspectors left positive impressions on teachers. The findings did not indicate that a school inspection was regarded as an intimidating event, as reported by other literature (Haris et al., 2018; Hopkins et al., 2016; Moreton, 2015). In fact, the inspectors' positive attitudes, like their kindness, friendliness and consideration, helped to enhance the ambience and reduce stress among the inspectees. The use of improper and harsh tones of voice when communicating, as discovered by previous studies (De Grauwe, 2008; Moswela, 2010; Wanzare, 2002), were also not found in this research. The intentions to look for mistakes or damage the teachers' professionalism, as discovered by other studies (Behnke \& Steins, 2017; Hopkins et al., 2016), were also not supported by the findings of this work.

On the other hand, the positive manner of the school inspectors, as presented in these findings, turned the school inspection event from being stressful and intimidating into an insightful experience. Overall, the participants described the school inspectors as friendly, kind, considerate and appreciative. The inspectors' demeanour during the school inspection is important and helpful in promoting a positive ambience during the inspection. The inspectors' benevolent, friendly and thoughtful attitude, their positive approach to communication and their provision of recognition to the teachers and administrators all helped to alleviate stress and minimise the undesirable effects of school inspections that had been suggested by Ehren and Visscher (2006). For an inspector to show an appreciative and friendly manner is also helpful in guaranteeing positive collaboration between the school and the inspectors, as well as in reducing the experience of anxiety among teachers (Behnke \& Steins, 2017).

These findings are somewhat different to the findings of Tahir et al (2018), although both studies were conducted in Malaysia. Their study discussed the experience of stress among deputy heads, with school inspections found to be one of the sources of stress. However, this study explored the teachers' and administrators' experiences of school inspections, whereby they were interviewed after the school inspection had taken place. This might indicate that some changes have occurred in the practices of school inspectors in Malaysia, such that their approaches have improved and they have become more friendly and less intimidating.

This study recommends that practitioners like school inspectors and other inspecting officers should show a positive attitude and apply a good communication approach. They should also become friendlier and thoughtful while working with teachers and school administrators as their compassion, kindness and consideration when conducting the examination can make the process easier for school staff. It can encourage the staff to learn and make improvements based on the process while limiting the occurrence of unwanted effects like stress. Future 
studies can explore the links between school inspectors' characteristics and any school improvements that derived from the outcomes of an inspection. To conclude, the approach, personality and features of the inspection, as presented by the school inspector, play a pivotal role in shaping the experience of the inspectees, making the process less stressful and more meaningful, as well as minimising and preventing the potential negative side effects.

\section{Acknowledgement}

This study was funded by the Ministry of Higher Education, Malaysia.

\section{References}

Alexius, K. (2018). Abuse, degradation and conflicts in school. A qualitative study of text documents in cases at the Swedish Schools Inspectorate. International Journal of Law, Crime and Justice, 54, 66-74.

Ali, N. J. M., Kadir, S. A., Krauss, S. E., Basri, R., \& Abdullah, A. (2021). A Proposed Framework of School Inspection Outcomes: Understanding Effects of School Inspection and Potential Ways to Facilitate School Improvement. International Journal of Academic Research in Business and Social Sciences, 11(2), 418-435.

Behnke, K., \& Steins, G. (2017). Principals' reactions to feedback received by school inspection: A longitudinal study. Journal of Educational Change, 18(1), 77-106.

Brimblecombe, N., Ormston, M., \& Shaw, M. (1995). Teachers' Perceptions of School Inspection: A stressful experience. Cambridge Journal of Education, 25(1), 53-61.

Brimblecombe, N., Ormston, M., \& Shaw, M. (1996). Gender Differences in Teacher Response to School Inspection. Educational Studies, 22(1), 27-40.

Creswell, J. W. (2012). Qualitative Inquiry and Research Design: Choosing Among Five Approaches. SAGE Publications.

De Grauwe, A. (2008). School Monitoring Systems and their Impact on Disparities. In Unesco. http://unesdoc.unesco.org/images/0018/001800/180083e.pdf

de Wolf, I. F., \& Janssens, F. J. G. G. (2007). Effects and side effects of inspections and accountability in education: An overview of empirical studies. Oxford Review of Education, 33(3), 379-396.

Ehren, M. C. M., \& Visscher, A. J. (2006). Towards A Theory On Impact of School Inspection. British Journal of Educational Studies, 54(1), 51-72.

Fitz-Gibbon, C. T. (1997). Feasibility studies for a national system of value-added indicators. Curriculum, Evaluation and Management Centre, University of Durham.

Hamzah, M. I. M., \& Tahir, H. B. M. (2013). A glimpse into School Self-evaluation in Malaysia: Are we doing the right things? Or are we doing the things right? Asian Social Science, 9(12), 50-59.

Haris, I., Naway, F. A., Pulukadang, W. T., Takeshita, H., \& Ancho, I. V. (2018). School supervision practices in the indonesian education system; perspectives and challenges. Journal of Social Studies Education Research, 9(2), 366-387.

Hopkins, E., Hendry, H., Garrod, F., McClare, S., Pettit, D., Smith, L., Burrell, H., Temple, J., Hendry, H., Garrod, F., McClare, S., Pettit, D., Smith, L., Burrell, H., \& Temple, J. (2016). Teachers' views of the impact of school evaluation and external inspection processes. Improving Schools, 19(1), 52-61.

Hult, A., \& Segerholm, C. (2016). The process of juridification of school inspection in Sweden 1. Scandinavian Journal of Educational Research, 25(2), 95-118.

Kementerian Pendidikan Malaysia. (2015). Pelan Pembangunan Pendidikan Malaysia 2015- 
2025 (Pendidikan Tinggi).

MacBeath, J. (2006). School inspection and self-evaluation: Working with the new relationship. In School Inspection and Self-Evaluation: Working with the New Relationship. Routledge.

Male, D. B. (2006). Special school inspection and its effects on teachers' stress and health, workload and job-related feelings: a case study. European Journal of Special Needs Education, 14(3), 254-268.

Merriam, S. B. (1998). Qualitative Research and Case Study Applications in Education. JosseyBass.

Merriam, S. B., \& Tisdell, E. J. (2016). Qualitative Research: A Guide to Design and Implementation (4th ed.). Jossey-Bass.

Moreton, H. J. (2015). Headteacher inspectors: boundaries, identity and the potential for system leadership. Sheffield Hallam University.

Moswela, B. (2010). Instructional supervision in Botswana secondary schools: An investigation. Educational Management Administration and Leadership, 38(1), 71-87.

OECD. (2013). Synergies for Better Learning: An International Perspective on Evaluation and Assessment. OECD Publising.

Penninckx, M., Vanhoof, J., De Maeyer, S., \& Van Petegem, P. (2015). Enquiry into the side effects of school inspection in a 'low-stakes' inspection context. Research Papers in Education, 31(4), 462-482.

Perryman, J. (2007). Inspection and emotion. 37(2), 173-190.

Quintelier, A., Vanhoof, J., \& De Maeyer, S. (2018). Understanding the influence of teachers' cognitive and affective responses upon school inspection feedback acceptance. Educational Assessment, Evaluation and Accountability, 30(4), 399-431.

Richards, L., \& Morse, J. M. (2013). README FIRST for a User's Guide to Qualitative Methods (3rd ed.). SAGE Publications.

Segerholm, C., \& Hult, A. (2016). Learning from and Reacting to School Inspection - Two Swedish Case Narratives Learning from and Reacting to School Inspection - Two Swedish. Scandinavian Journal of Educational Research, 1-15.

Smith, P. (1995). On the unintended consequences of publishing performance data in the public sector. International Journal of Public Administration, 18(2-3), 277-310.

Tahir, L., Musah, M. B., Panatik, S. A., Ali, M. F., \& Said, M. N. H. M. (2018). Primary school leadership in Malaysia: The experience of stress among deputy heads. Educational Management Administration and Leadership, 47(5), 785-814.

Wanzare, Z. O. (2002). Rethinking Teacher Evaluation in the Third World: The Case of Kenya. Educational Management Administration \& Leadership, 30(2), 213-229. 